\title{
Ovulation rate, embryo survival and ovarian sensitivity to gonadotrophins in mice selected for litter size and body weight
}

\author{
Barbara S. Durrant*, E. J. Eisen and L. C. Ulberg \\ Department of Animal Science, North Carolina State University, Raleigh, \\ North Carolina 27650, U.S.A.
}

\begin{abstract}
Summary. Single trait selection of mice for either large body size or large litter size resulted in an increased ovulation rate because of possible enhanced ovarian sensitivity to gonadotrophins. There was no difference in pre-implantation embryonic survival in either of the selected lines when compared to control mice. Selection for body weight did not alter post-implantation embryo survival, but fewer fetuses were lost after implantation in the litter size line compared to the control line. Index selection for large body size and small litter size did not change ovulation rate but increased pre- and post-implantation embryonic mortality. Selection for small body size and large litter size increased ovulation rate and decreased early embryonic death.
\end{abstract}

\section{Introduction}

Litter size is determined by the number of ova shed, fertilization rate, and pre- and post-implantation embryonic mortality. Selection for large litter size in mice results in an increase in ovulation rate (Falconer, 1960; Joakimsen \& Baker, 1977; Bakker, Wallinga \& Politiek, 1978) and, in some strains, a decrease in embryo loss (Bakker et al., 1978). Mice selected for small litter size respond with increased embryonic mortality which may (Bateman, 1966; Joakimsen \& Baker, 1977) or may not (Land \& Falconer, 1969) be accompanied by a decrease in ovulation rate. In studies involving the crossing of selected lines of mice, Bradford \& Nott (1969) concluded that ovulation rate and embryonic survival are controlled by independent genetic systems. They also found that the two components of embryonic survival, pre- and post-implantation viability, are controlled by different genes.

Ovulation rate is influenced by activity of circulating gonadotrophins and ovarian sensitivity to these hormones which are under independent genetic control in mice (Land \& Falconer, 1969). McLaren (1962) found that selection for litter size changed ovulation rate as the result of altered ovarian sensitivity to FSH. The positive genetic correlation between litter size and body weight in mice has been recognized for many years (MacArthur, 1944; Falconer, 1953; Elliott, Legates \& Ulberg, 1968; Eisen, 1973). Correlated responses in litter size following selection for body weight are due to changing the ovulation rate in the same direction as body weight (Fowler \& Edwards, 1960). To explore further the correlation between litter size and body weight, Eisen (1978) developed two single-trait and two index-selected lines of mice, for which litter size and/or 6-week body weight were used as selection criteria.

It was the purpose of the present study to describe the physiological changes resulting from

* Present address: Zoological Society of San Diego, San Diego, California 92112, U.S.A. 
selection for litter size and/or body weight. Ovulation and fertilization rates, pre- and post-implantation embryo death, ovarian sensitivity to gonadotrophins and embryo metabolism were studied.

\section{Materials and Methods}

The selected lines of mice used in these experiments were derived from a random-bred ICR population described by Eisen \& Hanrahan (1974). The base population of females had a mean 6-week body weight of $27.7 \mathrm{~g}$ and a mean litter size at birth of 12.2 young with respective standard deviations of $2 \cdot 4$ and $2 \cdot 5$.

A description of the first 12 generations of selection response was given by Eisen (1978). In this study all experiments included an unselected control line $(\mathrm{K})$ and 4 selected lines: $\mathrm{L}^{+}$, large litter size at birth in primiparous females; $\mathrm{W}^{+}$, large 6-week body weight; $\mathrm{L}^{+} \mathrm{W}^{-}$, large litter size and small body weight; $\mathrm{L}^{-} \mathrm{W}^{+}$, small litter size and large body weight. Selection was carried out concurrently in all lines.

Ovulation rate and embryo survival were studied in two different generations. The first (sampled from generation 16 of selection) was completed during the spring and the second (generation 18) was carried out during the following fall. Differences between generations due to selection were expected to be small; therefore, in any discussions on statistical analysis the two samples were regarded as two replicates. Mean litter size at birth and 6-week body weight were recorded for the remainder of the females in these two generations. Virgin females from the litters of primiparous females, whose litters were standardized to 8 young at 1 day of age, were used in all experiments. Age at mating was a covariable and ranged from 60 to 120 days. Females were weighed on the day a copulatory plug was detected (Day 0) and randomly assigned to one of two autopsy days, Day 2 or between Days 7 and 16. Ovarian sensitivity to gonadotrophins was measured using females from the 19th generation of selection.

Purina Laboratory Chow and water were always available. The laboratory was maintained at $21 \pm 1{ }^{\circ} \mathrm{C}$, relative humidity of $50-60 \%$, and a $12 \mathrm{~h}$ light: $12 \mathrm{~h}$ dark cycle.

The general design of the experiment is illustrated in Text-fig. 1. Details of each phase of the design are described below.

\section{Ovulation rate and early embryo loss}

Mice were killed at about 13:00 h on Day 2 and the ovaries were weighed. Embryos were recovered by flushing oviducts with Brinster's Medium for ovum culture (BMOC: Brinster, 1965). At this time most embryos were in the 8-cell stage, but unfertilized ova were still intact. Embryos and ova from each mouse were used to estimate ovulation rate. They were classified morphologically to determine fertilization rate and preimplantation viability. If an embryo appeared to be normal but had divided beyond the 8-cell stage it was classified as advanced. Embryos of normal appearance that had not reached the 8-cell stage were considered delayed. Degenerating embryos and unfertilized ova were collectively listed as DU.

Groups of 5 or 10 morphologically normal 8-cell embryos were washed and cultured for $3 \mathrm{~h}$ in $1 \mathrm{ml} \mathrm{BMOC}$ with $5 \mu \mathrm{Ci}\left[{ }^{3} \mathrm{H}\right]$ leucine at $37^{\circ} \mathrm{C}$ with $5 \% \mathrm{CO}_{2}$ circulating in air. After incubation the embryos were washed with fresh $\mathrm{BMOC}_{2}$ and examined; those still appearing normal were digested and assayed for acid-precipitable protein, by the technique described by Durrant \& Ulberg (1976), as a measure of embryo metabolism. Disintegrations per minute (d.p.m.) were divided by the number of embryos in each culture group to obtain an average d.p.m. 


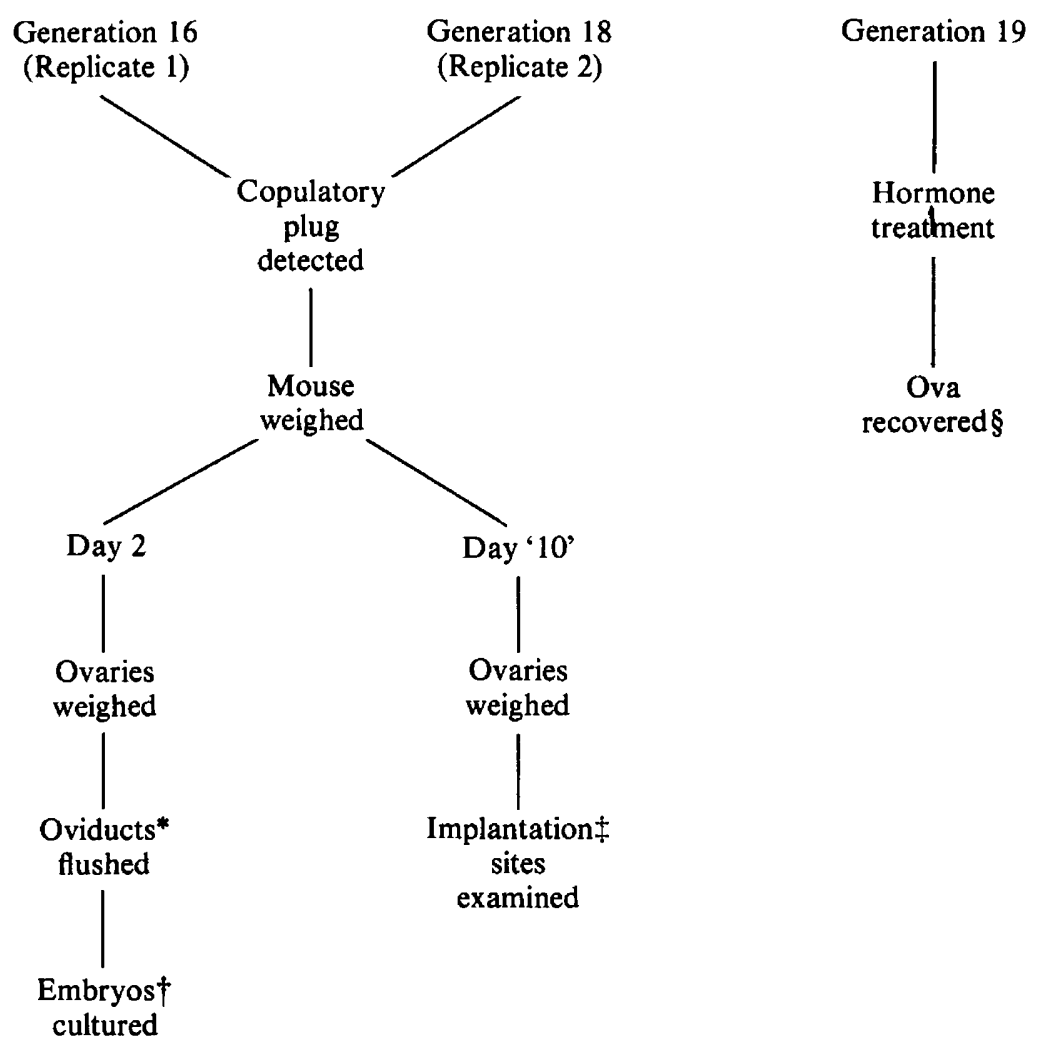

Text-figure 1. Outline of the experimental design used for the study of 5 selected lines of mice. * Spontaneous ovulation rate and pre-implantation loss; $\uparrow$ embryo metabolism; $\ddagger$ post-implantation loss and litter size; §ovulation rate in response to gonadotrophins.

\section{Post-implantation fetal death}

Females were autopsied between 7 and 16 days of gestation and ovaries were weighed. The modal value, Day ' 10 ', and the term fetuses is subsequently used to describe autopsies on Days 7-16. Each uterine horn was examined for implantation sites and fetuses of normal appearance. The number of abnormal fetuses was used as an estimate of post-implantation embryo loss, while the number of normal fetuses was used to estimate litter size.

\section{Ovarian sensitivity to gonadotrophins}

At 56 days of age virgin females, regardless of body weight, were induced to ovulate with 0.5 mg FSH followed $43 \mathrm{~h}$ later by 2.5 i.u. hCG. At $18-20 \mathrm{~h}$ after hCG injection the mice were killed and embryos were flushed from the ampulla of the oviduct and counted. The number of ova shed was used as a measure of ovarian sensitivity to the hormones.

\section{Statistical analysis}

The data were analysed by least squares analysis of variance or $\chi^{2}$ procedures (Snedecor \& Cochran, 1967). The effects of line, replicate and line by replicate interaction on litter size, body weight, ovary weight, age at mating, ovulation rate, and pre- and post-implantation embryo loss were determined. Covariates were added to the model when statistical significance deemed it appropriate. Means were compared using a least significant difference test. 


\section{Results and Discussion}

As shown in Table 1, there was no significant change in litter size between generations for any line. Body weight increased $(P<0.01)$ from the 16th to the 18 th generation in all lines except $\mathrm{L}^{+} \mathrm{W}^{-}$which remained unchanged.

Table 1. Mean litter size and 6-week body weight of female mice of selected lines

\begin{tabular}{|c|c|c|c|c|c|c|}
\hline \multirow[b]{2}{*}{ Line } & \multicolumn{3}{|c|}{ Generation 16} & \multicolumn{3}{|c|}{ Generation 18} \\
\hline & $\begin{array}{l}\text { No. of } \\
\text { mice }\end{array}$ & $\begin{array}{l}\text { Body } \\
\text { wt (g) }\end{array}$ & $\begin{array}{l}\text { Litter } \\
\text { size }\end{array}$ & $\begin{array}{c}\text { No. of } \\
\text { mice }\end{array}$ & $\begin{array}{l}\text { Body } \\
\text { wt (g) }\end{array}$ & $\begin{array}{c}\text { Litter } \\
\text { size }\end{array}$ \\
\hline $\mathbf{K}$ & 96 & $24 \cdot 48^{\mathrm{a}}$ & $12 \cdot 17^{a}$ & 95 & $26.77^{a}$ & $12 \cdot 61^{a}$ \\
\hline $\mathrm{L}^{+}$ & 100 & $29 \cdot 24^{b}$ & $16 \cdot 74^{b}$ & 98 & $30 \cdot 67^{b}$ & $17 \cdot 31^{b}$ \\
\hline $\mathbf{w}^{+}$ & 103 & $34 \cdot 68^{c}$ & $14 \cdot 00^{\mathrm{c}}$ & 101 & $37.02^{c}$ & $14 \cdot 22^{\mathrm{c}}$ \\
\hline $\mathbf{L}^{-} \mathbf{W}^{+}$ & 73 & $28 \cdot 74^{b}$ & $10 \cdot 84^{d}$ & 76 & $31 \cdot 93^{\mathrm{d}}$ & $10.49^{d}$ \\
\hline $\mathbf{L}^{+} \mathbf{W}^{-}$ & 108 & $23 \cdot 18^{d}$ & $14 \cdot 31^{c}$ & 106 & $23.45^{e}$ & $14.60^{c}$ \\
\hline
\end{tabular}

Values in the same column not sharing a common superscript are significantly different $(P<0.01)$.

\section{Ovulation rate and early embryo loss}

The various characteristics depicted in Table 2 were adjusted for age of dam, body weight or ovary weight when these factors were shown by analysis of covariance to be significant $(P<$ 0.05 ) and the adjusted means are also given in Table 2 . When there was no line by replicate interaction, means were pooled over replicates. For the 3 traits described in Table 2, replicate

Table 2. Physiological characteristics of mice examined at Day 2 of gestation

\begin{tabular}{|c|c|c|c|c|c|c|c|}
\hline & & & & & Selected line & & \\
\hline & Trait & Replicate & $\mathrm{K}$ & $\mathbf{L}^{+}$ & $\mathbf{W}^{+}$ & $\mathrm{L}^{-} \mathbf{W}^{+}$ & $\mathbf{L}^{+} \mathbf{W}^{-}$ \\
\hline (1) & & & $\begin{array}{c}30.9 \pm 0.5^{a} \\
(57)\end{array}$ & $37 \cdot 0 \pm 0.5^{0}$ & $\begin{array}{c}40.9 \pm 0.47^{c} \\
(50)\end{array}$ & $35 \cdot 9 \pm 0.5^{d}$ & $27.8 \pm 0.5^{e}$ \\
\hline & Body wt adjusted for & 1 & $30 \cdot 2 \pm 0.5^{a}$ & $36 \cdot 1 \pm 0 \cdot 6^{b}$ & $* 39 \cdot 0 \pm 0.6^{c}$ & $35 \cdot 5 \pm 0.6^{\mathrm{b}}$ & $26.8 \pm 0.6^{c}$ \\
\hline & & 2 & $31.7 \pm 0.7^{\mathrm{a}}$ & $38 \cdot 8 \pm 0.8^{b}$ & ${ }^{*} 43 \cdot 3 \pm 0 \cdot 7^{c}$ & $\begin{array}{c}35 \cdot 9 \pm 0.8^{d} \\
(17)\end{array}$ & $\begin{array}{c}28 \cdot 3 \pm 0 \cdot 8^{e} \\
(16)\end{array}$ \\
\hline (2) & $\begin{array}{l}\text { Ovary wt at Day } 2 \\
(\mathrm{mg})\end{array}$ & $1+2$ & $21 \cdot 7 \pm \frac{ \pm 1 \cdot 1^{\mathrm{ac}}}{(54)}$ & $30 \cdot 5 \pm \frac{1 \cdot 2^{b}}{(42)}$ & $29 \cdot 0 \pm 1 \cdot 1_{(48)}^{b}$ & $\begin{array}{c}23 \cdot 2 \pm 1 \cdot 2^{\mathrm{a}} \\
(47)\end{array}$ & $\begin{array}{c}19 \cdot 9 \pm 1 \cdot 2^{c} \\
(43)\end{array}$ \\
\hline & $\begin{array}{l}\text { Ovary wt adjusted for } \\
\text { age (mg) }\end{array}$ & $\begin{array}{l}1 \\
2\end{array}$ & $\begin{array}{l}* 18.8 \pm 1.3^{\mathrm{a}} \\
* 24.9 \pm 1.8^{\mathrm{a}}\end{array}$ & $\begin{array}{l}28.9 \pm 1.4^{b} \\
33.6 \pm 2.0^{b}\end{array}$ & $\begin{array}{l}* 23.8 \pm 1.4^{c} \\
* 34.7 \pm 1.7^{b}\end{array}$ & $\begin{array}{l}24 \cdot 1 \pm 1 \cdot 5^{\mathrm{c}} \\
24 \cdot 0 \pm 1 \cdot 9^{\mathrm{a}}\end{array}$ & $\begin{array}{l}* 15.8 \pm 1.4^{a} \\
* 23.4 \pm 2.0^{a}\end{array}$ \\
\hline & $\begin{array}{l}\text { Ovary wt adjusted for } \\
\text { Trait } 1\end{array}$ & $\begin{array}{l}1 \\
2\end{array}$ & $\begin{array}{l}* 24 \cdot 5 \pm 1 \cdot 1^{a} \\
* 28 \cdot 3 \pm 1 \cdot 5^{a}\end{array}$ & $\begin{array}{l}26 \cdot 4 \pm 1 \cdot 2^{a} \\
27 \cdot 0 \pm 1 \cdot 6^{a}\end{array}$ & $\begin{array}{l}* 17.4 \pm 1.3^{b} \\
* 21.9 \pm 1.7^{b}\end{array}$ & $\begin{array}{l}22 \cdot 0 \pm 1 \cdot 1^{c} \\
21 \cdot 2 \pm 1 \cdot 5^{b}\end{array}$ & $\begin{array}{l}* 26.3 \pm 1.4^{a} \\
* 31.8+1.8^{a}\end{array}$ \\
\hline (3) & Ovulation rate & $1+2$ & $11 \cdot 4 \pm 0.7^{\mathrm{a}}$ & $15 \cdot 2 \pm 0.8^{b}$ & $\begin{array}{c}14 \cdot 4 \pm 0 \cdot 7^{b c} \\
(50)\end{array}$ & $\begin{array}{c}12 \cdot 9 \pm 0.7^{\mathrm{ac}} \\
(48)\end{array}$ & $\begin{array}{c}13 \cdot 3 \pm 0 \cdot 7^{\mathrm{ab}} \\
(45)\end{array}$ \\
\hline & $\begin{array}{l}\text { Ovulation rate adjusted } \\
\text { for Trait } 1\end{array}$ & $1+2$ & $13.4 \pm 0.7^{a}$ & $13.6 \pm 0.8^{a}$ & $10.6 \pm 0.9^{b}$ & $12.2 \pm 0.7^{\mathrm{ab}}$ & $17.0 \pm 0.7^{c}$ \\
\hline & $\begin{array}{l}\text { Ovulation rate adjusted } \\
\text { for Trait } 2\end{array}$ & $1+2$ & $12 \cdot 1 \pm 0 \cdot 7^{\mathrm{a}}$ & $14 \cdot 3 \pm 0.8^{b}$ & $13 \cdot 6 \pm 0.7^{\mathrm{ab}}$ & $13 \cdot 1 \pm 0.7^{\mathrm{ab}}$ & $14.2 \pm 0.8^{b}$ \\
\hline
\end{tabular}

Values are mean \pm s.e.m. for the no. of animals in parentheses (first replicate, second replicate or pooled). Disparity in numbers for body weight and ovary weight measurements was due to loss of ovarian tissue during processing.

Means in the same row not sharing a common superscript are significantly different $(P<0.05)$.

* Significant $(P<0.05)$ difference between replicates. 
and line effects were significant $(P<0.05)$. Replicate by line interactions affected body weight at the time of mating adjusted for age, and ovary weight adjusted for either age or body weight at the time of mating. Means of the second replicate were consistently higher.

Comparison of Tables 1 and 2 reveals that body weight ranking among lines did not change from 6 weeks of age to mating. The $\mathrm{W}^{+}$line increased $(P<0.05)$ in the second replicate in all unadjusted characteristics. No other line showed a difference between the two replicates in any of the 3 unadjusted traits. Although body weight at mating increased with age in each experimental line, adjusting for age at mating did not change the relative ranking for this trait amongst the 5 lines. Although rank did not change, age adjustment in the second replicate resulted in a difference $(P<0.05)$ in weight at mating between the $\mathrm{L}^{+}$and $\mathrm{L}^{-} \mathrm{W}^{+}$lines. Age adjustment did not significantly change ovary weight within lines when averaged over replicates, but it did eliminate the difference $(P<0.05)$ between the $\mathrm{K}$ and $\mathrm{L}^{+} \mathrm{W}^{-}$lines in the first replicate.

Adjusting the ovarian weight 2 days after mating for the body weight at mating in the first replicate removed the differences in ovary weight among the $\mathrm{L}^{+}, \mathrm{L}^{+} \mathrm{W}^{-}$and $\mathrm{K}$ lines. In this replicate, the $\mathrm{W}^{+}$line also had the smallest ovaries in proportion to their body size. These changes in rank also occurred in the second replicate. In all comparisons the $\mathrm{L}^{+}$line had the largest or second largest ovary weights. Selection for litter size appeared to have increased ovary weight independent of body weight. Selection in the index lines had led to divergence in ovary weight adjusted for body weight, with the $\mathrm{L}^{+} \mathrm{W}^{-}$line having the largest adjusted ovary weights. The $\mathrm{L}^{+}$and $\mathrm{W}^{+}$lines had significantly $(P<0.05)$ higher ovulation rates than did mice in the $\mathrm{K}$ line, with the $\mathrm{L}^{+}$line mice producing the most ova. The correlated response in ovulation rate in $\mathrm{L}^{+} \mathrm{W}^{-}$mice approached statistical significance $(P<0.07) . \mathrm{L}^{-} \mathrm{W}^{+}$mice did not exhibit the decrease in ovulation rate observed by Bateman (1966) when he selected only for small litter size. After adjustment for body weight, the $\mathrm{L}^{+} \mathrm{W}^{-}$line had the highest ovulation rate and $\mathrm{W}^{+}$the lowest; both lines were significantly $(P<0.05)$ different from controls. On the basis of per $\mathrm{mg}$ ovary weight, mice selected for large litter size, $\mathrm{L}^{+}$and $\mathrm{L}^{+} \mathrm{W}^{-}$, had significantly $(P<0.05)$ higher ovulation rates than did control mice.

Table 3 shows the correlation coefficients calculated for the 3 traits discussed above. As might be expected, there was a positive $(P<0.01)$ correlation between body size and ovary weight within each of the 5 lines of mice. The significant $(P<0 \cdot 01)$ positive correlation between body weight at mating and ovulation rate in the $\mathrm{K}, \mathrm{L}^{+}$and $\mathrm{W}^{+}$lines was not observed in the $\mathrm{L}^{-} \mathbf{W}^{+}$or $\mathbf{L}^{+} \mathbf{W}^{-}$lines, but the correlations were homogeneous. All correlation coefficients describing the relationship between ovarian weight 2 days after mating and ovulation rate were positive with a pooled correlation of $0.30(P<0.01)$.

Table 3. Correlation coefficients of various traits measured at Day 2 after mating, pooled within replicates

\begin{tabular}{|c|c|c|c|c|c|c|c|}
\hline \multirow[b]{2}{*}{ Traits } & \multicolumn{5}{|c|}{ Line } & \multirow[b]{2}{*}{ Pooled } & \multirow[b]{2}{*}{$x^{2+}$} \\
\hline & K & $\mathrm{L}^{+}$ & $\mathbf{W}^{+}$ & $\mathbf{L}^{-} \mathbf{W}^{+}$ & $\mathbf{L}^{+} \mathbf{W}^{-}$ & & \\
\hline Ovarian wt at Day $2 \times$ body wt at mating & $0 \cdot 38^{* *}$ & $0.66^{* *}$ & $0.64^{* *}$ & $0.67^{* *}$ & $0 \cdot 52^{* *}$ & $0.59^{* *}$ & 5.9 \\
\hline $\begin{array}{l}\text { Ovarian wt at Day } 2 \times \text { no. of embryos } \\
\text { recovered }\end{array}$ & 0.21 & $0.43^{* *}$ & $0 \cdot 25$ & $0.32^{*}$ & $0 \cdot 18$ & $0 \cdot 30^{* *}$ & $2 \cdot 0$ \\
\hline $\begin{array}{l}\text { Body wt at mating } \times \text { no. of embryos } \\
\text { recovered at Day } 2\end{array}$ & $0.52^{* *}$ & $0.53^{* *}$ & $0.42^{* *}$ & 0.30 & 0.28 & $0.42^{* *}$ & $3 \cdot 5$ \\
\hline $\begin{array}{l}\text { No. of embryos recovered at Day } 2 \times \\
\text { degenerating and unfertilized eggs } \\
\text { at Day } 2\end{array}$ & 0.30 & 0.09 & 0.04 & $0.47^{* *}$ & 0.05 & 0.21 & 7.6 \\
\hline
\end{tabular}

${ }^{*} P<0.05,{ }^{* *} P<0.01$.

† Calculated with 4 d.f., to test homogeneity of correlation coefficients amongst lines. The values were not significant, indicating that all correlation coefficients were homogeneous. 
A significant $(P<0.01)$ correlation of 0.47 between ovulation rate and the number of degenerating and unfertilized eggs was found in the $\mathrm{L}^{-} \mathrm{W}^{+}$line. Although the total number of embryos recovered in this line was not significantly different from that in controls, the line has a smaller litter size (Table 1). Selection against litter size, even when selecting at the same time for increased body weight, has apparently decreased litter size by increasing the loss of pre-implantation embryos.

Table 4 depicts values used to calculate the percentage of the variation in ovulation rate that was due to body weight at mating and ovarian weight at Day 2. Pooled correlation coefficients utilized in the calculations are listed in Table 3. Most of the variation in ovulation rate accounted for by these factors was due to the effect of body weight at mating alone. The effect of ovary weight may be biased downward, however, due to the fact that weights were taken after ovulation.

Table 4. Variation in ovulation rate attributable to body size and ovarian weight

\begin{tabular}{lccc}
\hline Independent variable & $\mathrm{b} \pm$ s.e. $\dagger$ & $\mathrm{b}^{\prime} \ddagger$ & $\%$ variation \\
\hline Body wt at mating & $0.54 \pm 0.11^{*}$ & 0.37 & 13.91 \\
Ovary wt at Day 2 & $0.06 \pm 0.05$ & 0.08 & 0.64 \\
Joint effects & & & 3.52 \\
\hline $100 \times \mathrm{R}^{2}$ & & & 18.07 \\
\hline
\end{tabular}

$* P<0.01$.

$\dagger$ Partial regression coefficient \pm standard error; pooled within line by replicate subclasses after analysis of variance indicated homogeneity of subclass partial regressions.

¥ Standard partial regression.

$\S$ Coefficient of determination was partitioned as follows: $R^{2}=\left(b_{1}^{\prime}\right)^{2}+\left(b_{2}^{\prime}\right)^{2}+$ $2 b_{1}^{\prime} b_{2}^{\prime} r_{12}$ where $b_{1}^{\prime}$ and $b_{2}^{\prime}$ are standard partial regressions of ovulation rate on body wt at mating and ovary wt at Day 2, respectively, and $r_{12}$ is the correlation between body wt at mating and ovary wt at Day 2 .

Table 5 illustrates the classification of embryos from mice examined at Day 2, listing the frequencies of embryo condition for the 5 lines, pooled over replicates. Embryo condition at recovery in all selected lines was different $(P<0.01)$ from that in the control line. A deficiency of 8-cell embryos contributed to the significance of the differences between $\mathrm{K}$ and all selected lines. The high percentage of embryos in the $\mathrm{W}^{+}$and $\mathrm{L}^{-} \mathrm{W}^{+}$lines that were delayed in their development contributed to the significant difference between $K$ and these two lines. Data on litter size (Table 1) indicate that the delayed $\mathrm{W}^{+}$embryos survive to term. Those embryos that were delayed in the $\mathrm{L}^{-} \mathrm{W}^{+}$line most probably were the ones that did not continue to develop and were responsible for the smaller litter size at term. A greater percentage of the embryos in the $\mathrm{L}^{+}$and $\mathrm{L}^{+} \mathrm{W}^{-}$lines than in the $\mathrm{K}$ line had developed beyond the 8-cell stage. This may be due to an improved uterine environment which allows these mice to support a greater number of fetuses. In no case did the percentage of degenerating and unfertilized embryos contribute to the significance of the difference between selected and control lines.

Table 6 depicts mean incorporation of $\left[{ }^{3} \mathrm{H}\right]$ leucine into protein of mouse embryos of the 5 experimental lines. Replicate and line effects were shown by analysis of variance to influence incorporation significantly $(P<0.01$ and $P<0.05$, respectively). Least squares analysis indicated a significant $(P<0.05)$ difference between the $\mathrm{L}^{+}$and $\mathrm{L}^{-} \mathrm{W}^{+}$lines in replicate 1 . However, the absence of significant and repeatable differences in replicate 2 and large coefficients of variation that ranged from 63 to $110 \%$ led to the conclusion that the technique used was not sufficiently precise to reveal possible differences in the metabolism of the embryos studied. 
Table 5. Frequency of embryo condition at recovery on Day 2 and $\chi^{2}$ values $\dagger$

\begin{tabular}{lccccc}
\hline \multicolumn{5}{r}{ Condition } & \multicolumn{5}{c}{ Lines } \\
\cline { 2 - 6 } & $\mathrm{K}$ & $\mathrm{L}^{+}$ & $\mathrm{W}^{+}$ & $\mathrm{L}^{-} \mathrm{W}^{+}$ & $\mathrm{L}^{+} \mathrm{W}^{-}$ \\
\hline 8-cell & 47.59 & 41.06 & 38.88 & 27.31 & $36 \cdot 90$ \\
Advanced & 19.04 & 25.03 & 19.25 & 19.06 & 31.99 \\
Delayed & 14.08 & 17.35 & 25.22 & 31.86 & 14.73 \\
Degenerating or un- & 19.30 & 16.56 & 16.65 & 21.76 & $16 \cdot 37$ \\
$\quad$ fertilized & & & & & \\
Column $\chi^{2}$ & & $14.02^{* *}$ & $33.04^{* *}$ & $92 \cdot 24^{* *}$ & $35 \cdot 38^{* *}$ \\
\hline
\end{tabular}

$P<0.01$.

$\dagger$ Based on 3 d.f. Each selected line was compared to the control line.

Table 6. Mean \pm s.e.m. incorporation of $\left[{ }^{3} \mathrm{H}\right]$ leucine into protein of mouse embryos cultured in vitro

\begin{tabular}{lccrrr}
\hline & \multicolumn{2}{c}{ Replicate 1 } & & \multicolumn{2}{c}{ Replicate 2 } \\
\cline { 2 - 3 } \cline { 5 - 6 } \multicolumn{1}{c}{ Line } & $\mathrm{N} \dagger$ & d.p.m. & & $\mathrm{N} \dagger$ & d.p.m. \\
\hline $\mathrm{K}$ & 21 & $295 \cdot 2 \pm 67.4^{\mathrm{ab}}$ & & 17 & $159 \cdot 4 \pm 73 \cdot 3^{\mathrm{a}}$ \\
$\mathrm{L}^{+}$ & 25 & $162 \cdot 3 \pm 67 \cdot 4^{\mathrm{a}}$ & & 12 & $101 \cdot 8 \pm 99 \cdot 2^{\mathrm{a}}$ \\
$\mathrm{W}^{+}$ & 21 & $253 \cdot 5 \pm 70 \cdot 1^{\mathrm{ab}}$ & & 23 & $77 \cdot 1 \pm 64 \cdot 9^{\mathrm{a}}$ \\
$\mathrm{L}^{-} \mathrm{W}^{+}$ & 13 & $450 \cdot 8 \pm 76 \cdot 8^{\mathrm{b}}$ & & 6 & $133 \cdot 5 \pm 121 \cdot 5^{\mathrm{a}}$ \\
$\mathrm{L}^{+} \mathrm{W}^{-}$ & 15 & $348 \cdot 2 \pm 70 \cdot 1^{\mathrm{ab}}$ & & 13 & $165 \cdot 5 \pm 81 \cdot 0^{\mathrm{a}}$ \\
\hline
\end{tabular}

Numbers in the same column not bearing common superscripts are significantly $(P<0.05)$ different.

$\uparrow$ Number of cultures of groups of 5 or 10 embryos.

Mean litter sizes at birth in generations 16 and 18 (Table 1) often exceeded the ovulation rate as measured in this experiment. Perhaps the method of embryo recovery employed in this study was not maximally effective, but error was assumed to be constant across lines as all recoveries were performed by only one investigator.

The present study utilized a maintenance ration (Purina Laboratory Chow) which is lower in energy than the ration fed in the study by Eisen (1978) (Purina Mouse Chow). Increased ovulation rate of gilts following the intake of a high energy ration has been reported by many workers (Zimmerman, Spies, Self \& Casida, 1960; Kirkpatrick, Howland, First \& Casida, 1967), and a similar response in mice could explain the discrepancy between the litter sizes reported by Eisen (1978) and the ovulation rates observed in this study.

\section{Post-implantation fetal death}

There were no significant differences between right and left ovary weights or between the two uterine horns in the number of live and the number of dead fetuses, respectively. Ovary weight, therefore, refers to the sum of both ovaries, and the number of live and dead fetuses is combined for the two horns.

As shown in Table 7 , replicates significantly $(P<0.05)$ influenced the total number of live fetuses at autopsy, but since there were no significant replicate by line effects, means were pooled over replicates. Including both replicates, $5,1,3,10$ and 6 animals in lines $\mathrm{K}_{,} \mathrm{L}^{+}, \mathrm{W}^{+}, \mathrm{L}^{-} \mathrm{W}^{+}$ and $\mathrm{L}^{+} \mathrm{W}^{-}$, respectively, had no implantation sites. The differences from controls were significant $(P<0.05)$ in the $\mathrm{L}^{+}$and $\mathrm{L}^{-} \mathrm{W}^{+}$lines. These animals were not included in further statistical analysis of the data. 
Table 7. Physiological characteristics of mice examined at Day ' 10 ' of gestation

\begin{tabular}{|c|c|c|c|c|c|c|}
\hline \multirow[b]{2}{*}{ Trait } & \multirow[b]{2}{*}{ Replicate } & \multicolumn{5}{|c|}{ Selected line } \\
\hline & & K & $\mathrm{L}^{+}$ & $\mathrm{W}^{+}$ & $\mathrm{L}^{-} \mathrm{W}^{+}$ & $\mathrm{L}^{+} \mathrm{W}^{-}$ \\
\hline Body wt at mating $(\mathrm{g})$ & $1+2$ & $\begin{array}{c}31 \cdot 3 \pm 0 \cdot 4^{\mathrm{a}} \\
\quad(47)\end{array}$ & $\begin{array}{c}36 \cdot 2 \pm 0 \cdot 5^{b} \\
(30)\end{array}$ & $\begin{array}{c}41 \cdot 7 \pm 0 \cdot 5^{c} \\
(37)\end{array}$ & $\begin{array}{c}35.4 \pm 0.4^{b} \\
(47)\end{array}$ & $\begin{array}{c}28 \cdot 7 \pm 0 \cdot 5^{d} \\
(34)\end{array}$ \\
\hline $\begin{array}{l}\text { Body wt adjusted for } \\
\text { age (g) }\end{array}$ & $1+2$ & $31 \cdot 5 \pm 0.4^{\mathrm{a}}$ & $36 \cdot 3 \pm 0 \cdot 5^{b}$ & $41 \cdot 3 \pm 0.4^{\mathfrak{c}}$ & $35.4 \pm 0.4^{b}$ & $38 \cdot 6 \pm 0.5^{d}$ \\
\hline $\begin{array}{l}\text { Ovary wt at autopsy } \\
\text { (mg) }\end{array}$ & $1+2$ & $\begin{array}{c}16 \cdot 4 \pm 0 \cdot 6^{\mathrm{a}} \\
(54)\end{array}$ & $\begin{array}{c}20 \cdot 1 \pm 0 \cdot 7^{b} \\
(40)\end{array}$ & $\begin{array}{c}21.5 \pm 0.7^{b} \\
(43)\end{array}$ & $\begin{array}{c}17 \cdot 1 \pm 0 \cdot 6^{a} \\
(52)\end{array}$ & $\begin{array}{c}15 \cdot 7 \pm 0 \cdot 7^{\mathrm{a}} \\
(42)\end{array}$ \\
\hline $\begin{array}{l}\text { Ovary wt adjusted for } \\
\text { body wt (mg) }\end{array}$ & $1+2$ & $17 \cdot 0 \pm 0.7^{\mathrm{ac}}$ & $19.2 \pm 0.8^{b}$ & $18 \cdot 9 \pm 1.0^{\mathrm{ab}}$ & $16.4 \pm 0.6^{c}$ & $16 \cdot 5 \pm 1 \cdot 0^{\mathrm{ac}}$ \\
\hline $\begin{array}{l}\text { No. of live fetuses at } \\
\text { autopsy }\end{array}$ & $1+2$ & $\begin{array}{l}12 \cdot 9 \pm 0 \cdot 5^{a} \\
\quad(49)\end{array}$ & $\begin{array}{c}18 \cdot 2 \pm 0.6^{\mathrm{b}} \\
(39)\end{array}$ & $\begin{array}{c}14.6 \pm 0.6^{c} \\
(40)\end{array}$ & $\begin{array}{c}11 \cdot 6 \pm 0.6^{\mathrm{a}} \\
(42)\end{array}$ & $\begin{array}{c}15 \cdot 0 \pm 0 \cdot 6^{c} \\
(36)\end{array}$ \\
\hline $\begin{array}{l}\text { Live fetuses adjusted } \\
\text { for body wt }\end{array}$ & $1+2$ & $14 \cdot 2 \pm 0 \cdot 7^{\mathrm{a}}$ & $17.7 \pm 0.7^{b}$ & $11.4 \pm 1.0^{\mathrm{c}}$ & $11 \cdot 1 \pm 0 \cdot 6^{c}$ & $17 \cdot 3 \pm 1 \cdot 0^{b}$ \\
\hline $\begin{array}{l}\text { No. of dead fetuses at } \\
\text { autopsy }\end{array}$ & $1+2$ & $\begin{array}{c}0.74 \pm 0.2^{\mathrm{a}} \\
\quad(49)\end{array}$ & $\begin{array}{c}0.52 \pm 0.2^{\mathrm{a}} \\
(39)\end{array}$ & $\begin{array}{c}0.70 \pm 0.2^{a} \\
(40)\end{array}$ & $\begin{array}{c}1.4 \pm 0 \cdot 2^{b} \\
(42)\end{array}$ & $\begin{array}{c}0.85 \pm 0.2^{\mathrm{a}} \\
(36)\end{array}$ \\
\hline
\end{tabular}

Values are mean \pm s.e.m. for the no. of mice indicated in parentheses. Disparity in numbers of body weight and ovary weight measurements was due to unobserved copulatory plugs. Disparity in numbers of ovary weight measurements and litters examined was due to the absence of implantation sites in some mice in each line.

Means in the same row not sharing a common superscript are significantly different $(P<0.05)$.

Adjusting body weight at mating for age at mating or day of gestation did not significantly change line means or ranking. Similarly, body weight adjustment did not change ovary weight means.

The number of live fetuses at autopsy was an adequate predictor of litter size. The $\mathrm{L}^{+}$line, as expected, had a significantly $(P<0.05)$ larger number of fetuses surviving to Day ' 10 ' than did the control line. The $\mathrm{W}^{+}$and $\mathrm{L}^{-} \mathrm{W}^{+}$females also carried more $(P<0.05)$ young than did control mice. Age of mother adjustment of this trait did not change line means, but body weight at mating adjustment reduced the number of live fetuses in the $\mathrm{W}^{+}$line to values below control means and increased the $\mathrm{L}^{+} \mathrm{W}^{-}$mean to a level similar to that of the $\mathrm{L}^{+}$line.

Although the number of dead fetuses at autopsy was significantly $(P<0.05)$ higher in the $\mathrm{L}^{-} \mathrm{W}^{+}$line than in the $\mathrm{K}$ line, the frequency of post-implantation deaths in the two lines was not different. Adjustment for the day of gestation on which autopsy was performed did not alter mean numbers of dead fetuses.

No significant correlations were found between ovary weight at autopsy (Day '10') and body weight at mating. These data are in contrast with the results at Day 2 in which ovarian weight was positively and significantly $(P<0.01)$ correlated with body weight at mating in each line. Body weights of dams at mating were not different for the two stages of gestation studied, but ovary weights had decreased between Day 2 and Day ' 10 ', perhaps due to a loss of fluid or luteal tissue.

Percentages of live and dead fetuses in each line at autopsy are shown in Table 8 . The $\mathrm{L}^{+}$line exhibited a significant $(P<0.01)$ reduction in the percentage of dead fetuses compared to the controls. The percentage of dead fetuses in the $\mathrm{L}^{-} \mathrm{W}^{+}$line was greater $(P<0.05)$ than in the $\mathrm{K}$ line. The $\mathrm{W}^{+}$and $\mathrm{L}^{+} \mathrm{W}^{-}$selected lines were similar to the control line.

\section{Ovarian sensitivity to gonadotrophins}

The body weight at 6 weeks and mean numbers of ova shed in response to hormone treatment are shown in Table 9 . Ovulation was induced in $97 \%$ of the mice; 7 animals failed to ovulate, 3 in $\mathrm{L}^{+} \mathrm{W}^{-}, 2$ in $\mathrm{L}^{-} \mathrm{W}^{+}$, and 1 each in the $\mathrm{L}^{+}$and $\mathrm{K}$ lines. These mice were not included in the statistical analysis of the data. 
Table 8. Frequency of live and dead fetuses at Day ' 10 ' of gestation and $\chi^{2}$ values $\dagger$

\begin{tabular}{lccccr}
\hline & \multicolumn{5}{c}{ Line } \\
\cline { 2 - 6 } Condition & $\mathrm{K}$ & $\mathrm{L}^{+}$ & $\mathrm{W}^{+}$ & $\mathrm{L}^{-} \mathrm{W}^{+}$ & $\mathrm{L}^{+} \mathrm{W}^{-}$ \\
\hline Live & 89.86 & $93 \cdot 76$ & 91.45 & $86 \cdot 22$ & $90 \cdot 53$ \\
Dead & $10 \cdot 14$ & $6 \cdot 24$ & $8 \cdot 55$ & $13 \cdot 78$ & 9.47 \\
Column $\chi^{2}$ & & $7 \cdot 34^{* *}$ & 1.02 & $4.05^{*}$ & 0.17 \\
\hline
\end{tabular}

* $P<0.05,{ }^{* *} P<0.01$.

$\dagger$ Based on 1 d.f. Each selected line was compared to the control line.

Table 9. Mean \pm s.e.m. 6-week body weights and induced ovulation rates of gonadotrophin-stimulated mice

\begin{tabular}{lccccc}
\hline & \multicolumn{5}{c}{ Line } \\
\cline { 2 - 6 } & $\mathrm{K}$ & $\mathrm{L}^{+}$ & $\mathrm{W}^{+}$ & $\mathrm{L}^{-} \mathrm{W}^{+}$ & $\mathrm{L}^{+} \mathrm{W}^{-}$ \\
\hline No. of mice & 59 & 42 & 59 & 41 & 45 \\
6-week body weight $(\mathrm{g})$ & $26.3 \pm 0.3^{\mathrm{a}}$ & $30.6 \pm 0.4^{\mathrm{b}}$ & $35.3 \pm 0 \cdot 3^{\mathrm{c}}$ & $29 \cdot 8 \pm 0.4^{\mathrm{b}}$ & $23 \cdot 2 \pm 0.4^{\mathrm{d}}$ \\
Induced ovulation rate $\dagger$ & $10.8 \pm 0.6^{\mathrm{a}}$ & $13.9 \pm 0.7^{\mathrm{b}}$ & $13.9 \pm 0 \cdot 6^{\mathrm{b}}$ & $12.4 \pm 0.7^{\mathrm{ab}}$ & $11.6 \pm 0.7^{\mathrm{a}}$ \\
\hline
\end{tabular}

Values in the same row not bearing a common superscript are significantly different $(P<0.05)$.

$\dagger$ No. of embryos recovered per mouse.

The single trait selected lines had significantly $(P<0.05)$ higher ovulation rates than the control line. Selection for body weight and against litter size was successful in increasing $(P<$ 0.01 ) body weight but did not change ovarian response to gonadotrophins. Similarly, mice of the $\mathrm{L}^{+} \mathrm{W}^{-}$line were smaller $(P<0.05)$ than those of the control line but had the same induced ovulation rate. It appears that genes controlling body weight are able to exert their effect despite the antagonistic selection for litter size. More than 20 eggs were produced in response to the hormone treatment by 19 and $12 \%$ of the mice in lines $\mathrm{L}^{+}$and $\mathrm{W}^{+}$, respectively, compared to $3 \%$ of the $\mathrm{K}$ line and 5 and $4 \%$ of the $\mathrm{L}^{-} \mathrm{W}^{+}$and $\mathrm{L}^{+} \mathrm{W}^{-}$lines, respectively. The correlation coefficient of 0.16 between 6 -week body weight and numbers of ova shed was not significant.

\section{General Discussion}

Single trait selection for litter size increased body weight and ovary weight compared with that in control mice. Ovulation rate and post-implantation survival were higher in the $\mathrm{L}^{+}$line than the $\mathrm{K}$ line. Frequencies of pre-implantation embryo deaths in the $\mathrm{L}^{+}$and $\mathrm{K}$ lines were similar and $\mathrm{L}^{+}$ mice had 4-6 more young than did $\mathrm{K}$ mice at autospsy. On a per $\mathrm{g}$ body weight basis, the $\mathrm{L}^{+}$ mice received less FSH and hCG and responded by releasing more ova than $\mathrm{K}$ mice, indicating an increased sensitivity of the ovaries to the hormones in the selected line. Data on the $\mathrm{L}^{+}$line agree with McLaren's (1962) findings that 3 strains of mice selected for litter size shed significantly different numbers of ova in response to a standard dose of FSH. Increased ovarian sensitivity to gonadotrophins and reduced post-implantation embryo mortality contribute to increased litter size in the $\mathrm{L}^{+}$selected line.

Selection based solely on body weight at 6 weeks in the $\mathrm{W}^{+}$line resulted in large increases in body weight and ovary weight over controls. At Day 2 of gestation, ovary weight/g body weight

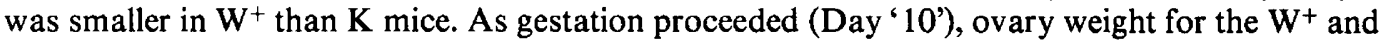
$\mathrm{K}$ lines was equal when adjusted for body weight. Ovulation rate in $\mathrm{W}^{+}$mice was higher than in $\mathrm{K}$ mice but, when adjusted for body weight at mating, ovulation rate in $\mathrm{W}^{+}$mice was lower than in controls. The percentage of live and dead fetuses in the $\mathrm{W}^{+}$line at ' 10 ' days of gestation was the same as in the $\mathrm{K}$ line, but $\mathrm{W}^{+}$females carried 2 more young than did the controls. Standard 
doses of FSH and hCG elicited the ovulation of more ova in $\mathrm{W}^{+}$mice than in $\mathrm{K}$ mice. Larger mice with proportionately small ovaries $\left(\mathrm{W}^{+}\right.$versus $\mathrm{K}$ ) were attaining higher ovulation rates, possibly due to increased ovarian sensitivity to gonadotrophins.

Endogenous gonadotrophin levels at the time of hormone treatment or the effects of previous gonadotrophin or steroid levels on the ovary or pituitary (Peckham, Yamaji, Dierschke \& Knobil, 1973; Bogdanova, Nolin \& Campbell, 1975) may account for the differences in induced ovulation rates between the lines of mice. Fowler \& Edwards (1960) administered PMSG to mice selected for large or small body size in doses that approximated their natural ovulation rates. Because different doses of PMSG were required they concluded that FSH secretion was different in the two lines. Another explanation for the results of Fowler \& Edwards (1960) is that the selection changed ovarian sensitivity to FSH. When endogenous gonadotrophins were removed by hypophysectomy in mice selected for high ovulation rate, the animals responded to a standard dose of PMSG with a significantly higher ovulation rate than did those of a control line (Bindon \& Pennycuik, 1974). Edwards (1962) found no difference in the unit potency of the gonadotrophins for mice selected for large or small body size. These studies and the results of the current experiment suggest that selection for litter size or body weight changes ovulation rate by increasing ovarian sensitivity to gonadotrophins.

Index selection in the $\mathrm{L}^{-} \mathrm{W}^{+}$line resulted in an increase in body weight at 6 weeks and at mating. Ovary weights in this index line were similar to those of controls at Day 2 and Day ' 10 '. Spontaneous and induced ovulation rates were the same for the $\mathrm{L}^{-} \mathrm{W}^{+}$and $\mathrm{K}$ mice. The smaller litter size observed by Eisen (1978) was due to increased pre- and post-implantation embryo loss. The contrasting index line, $\mathrm{L}^{+} \mathrm{W}^{-}$, had smaller body weights at 6 weeks and mating than did controls. Ovary weights and frequency of post-implantation death were similar in $\mathrm{L}^{+} \mathrm{W}^{-}$and $\mathrm{K}$ mice. An increase in ovulation rate in the $\mathrm{L}^{+} \mathrm{W}^{-}$line resulted in 2 more young per litter than in $\mathrm{K}$ mice when autopsied at Day ' 10 '. A greater percentage of advanced embryos in this line can be attributed to enhanced embryo viability or improved uterine environment. Moore, Eisen \& Ulberg (1970) found a $12.9 \%$ higher prenatal survival in mice selected for high 6-week body weight $\left(\mathrm{H}_{6}\right)$ compared to mice selected for low 6-week body weight $\left(\mathrm{L}_{6}\right)$. Moore et al. (1970) used intra- and inter-line embryo transfers between $\mathrm{H}_{6}$ and $\mathrm{L}_{6}$ mice and found that more $\mathrm{L}_{6}$ blastocysts survived to term regardless of the uterus in which they were placed, while more $\mathrm{L}_{6}$ recipients littered regardless of the genotype of the embryo. Increased survival in the $\mathrm{L}_{6}$ line was therefore due to the genotype of the embryo and the uterus. In addition to an increased ovulation rate, the success of the $\mathrm{L}^{+} \mathrm{W}^{-}$line in producing large litters may be the combination of these two factors which may bring about a beneficial synchrony between the function of the uterus and the growth of embryos.

A measure of embryo metabolism other than the one described here (glucose utilization or $\mathrm{CO}_{2}$ production, for example) may be successful in showing differences between the lines. Perhaps the selection of only morphologically normal 8-cell embryos for culture masked any differences in protein synthesis occurring between the selected lines. To test the theory that slowly developing embryos in the $\mathrm{W}^{+}$line survive to term while those in the $\mathrm{L}^{-} \mathrm{W}^{+}$line die, delayed embryos from the two lines should be assayed and compared. Significant metabolic differences would lend support to the theory and perhaps lead to the establishment of 'viability standards' with which to compare embryos of other lines of mice. If differences in metabolism can be measured, the reasons for the differences could be explored. Bazer, Robison, Clawson \& Ulberg (1969), working with uterine capacity in swine, have suggested that there is competition among embryos for some "critical biochemical substance" produced by the uterus that is very important in a key stage of embryo development. Perhaps the $\mathrm{L}^{+} \mathrm{W}^{-}$uteri are producing larger quantities or an altered form of such a critical substance which enhances embryo growth. Collection and analysis of uterine secretions during gestation and the subsequent culture of embryos in the secretions, coupled with a metabolism assay, could contribute greatly to the understanding of the physiological basis of selection for fecundity. 
Further studies of the other component parts of the litter size system are needed. Certain aspects of post-implantation embryo survival, such as uterine blood supply and placental transfer of nutrients and metabolities, could be examined to define further the physiological mechanisms controlling embryo survival. Detailed analysis of altered ovarian sensitivity to gonadotrophins due to selection would yield information essential to the understanding of ovary function.

Paper No. 6126 of the Journal Series of North Carolina Agricultural Research Service, Raleigh. The use of trade names in this publication does not imply endorsement by the North Carolina Agricultural Research Service of the products named, nor criticism of similar ones not mentioned.

\section{References}

Bakker, H., Wallinga, J.H. \& Politiek, R.D. (1978) Reproduction and body weight of mice after longterm selection for large litter size. J. Anim. Sci. 46, $1572-1580$.

Bateman, N. (1966) Ovulation and post-ovulational losses in strains of mice selected from large and small litters. Genet. Res. 8, 229-241.

Bazer, F.W., Robison, O.W., Clawson, A.J. \& Ulberg, L.C. (1969) Uterine capacity at two stages of gestation in gilts following embryo superinduction. $J$. Anim. Sci. 29, 30-34.

Bindon, B.M. \& Pennycuik, P.R. (1974) Differences in ovarian sensitivity of mice selected for fecundity. $J$. Reprod. Fert. 36, 221-224.

Bogdanova, E.M., Nolin, J.M. \& Campbell, G.T. (1975) Qualitative and quantitative gonad-pituitary feedback. Recent Prog. Horm. Res. 31, 567-619.

Bradford, G.E. \& Nott, C.F.G. (1969) Genetic control of ovulation rate and embryo survival in mice. II. Effects of crossing selected lines. Genetics, Princeton 63, 907-918.

Brinster, R.L. (1965) Studies on the development of mouse embryos in vitro. IV. Interaction of energy sources. J. Reprod. Fert. 10, 227-240.

Durrant, B.S. \& Ulberg, L.C. (1976) Mouse embryos as a measure of uterine function. J. Anim. Sci. 42, 270, Abstr.

Edwards, R.G. (1962) The size and endocrine activity of the pituitary in mice selected for large or small body size. Genet. Res. 3, 428-443.

Eisen, E.J. (1973) Genetic and phenotypic factors influencing sexual maturation of female mice. $J$. Anim. Sci. 37, 1104-1111.

Eisen, E.J. (1978) Single-trait and antagonistic index selection for litter size and body weight in mice. Genetics, Princeton 88, 781-811.

Eisen, E.J. \& Hanrahan, J.P. (1974) Genetic drift and inbreeding depression measured from control populations of mice. Can. J. Genet. Cytol. 16, 91-104.
Elliott, D.S., Legates, J.E. \& Ulberg, L.C. (1968) Changes in the reproductive processes of mice selected for large and small body size. J. Reprod. Fert. 17, 9-18.

Falconer, D.S. (1953) Selection for large and small size in mice. $J$. Genet. 1, 470-501.

Falconer, D.S. (1960) The genetics of litter size in mice. J. cell. comp. Physiol. 56, 153-167.

Fowler, R.E. \& Edwards, R.G. (1960) The fertility of mice selected for large or small body size. Genet. Res. 1, 393-407.

Joakimsen, O. \& Baker, R.L. (1977) Selection for litter size in mice. Acta agric. Scand. 27, 301-318.

Kirkpatrick, R.L., Howland, B.E., First, N.L. \& Casida, L.E. (1967) Some characteristics associated with feed and breed differences in ovulation rate in the gilt. J. Anim. Sci. 26, 188-192.

Land, R.B. \& Falconer, D.S. (1969) Genetic studies of ovulation rate in the mouse. Genet. Res. 13, 25-46.

MacArthur, J.W. (1944) Genetics of body size and related characteristics. II. Satellite characters associated with body size in mice. Am. Nat. 78, 224-237.

McLaren, A. (1962) The relation between natural fecundity and response to FSH. J. Endocr. 25, 137-144.

Moore, R.W., Eisen, E.J. \& Ulberg, L.C. (1970) Prenatal and post-natal maternal influences on growth in mice selected for body weight. Genetics, Princeton 64, 59-60.

Peckham, W.D., Yamaji, T., Dierschke, D.J. \& Knobil, E. (1973) Gonadal function and the biological and physicochemical properties of follicle stimulating hormone. Endocrinology 92, 1660-1666.

Snedecor, G.W. \& Cochran, W.G. (1967) Statistical Methods, 6th edn. Iowa State University Press, Ames.

Zimmerman, D.R., Spies, H.G., Self, H.L. \& Casida, L.E. (1960) Ovulation rate in swine as affected by increased energy intake just prior to ovulation. $J$. Anim. Sci. 19, 295-301. 